NBER WORKING PAPER SERIES

\title{
THE EFFECT OF MANDATED STATE EDUCATION SPENDING ON TOTAL LOCAL RESOURCES
}

\author{
Katherine Baicker \\ Nora Gordon \\ Working Paper 10701 \\ http://www.nber.org/papers/w10701 \\ NATIONAL BUREAU OF ECONOMIC RESEARCH \\ 1050 Massachusetts Avenue \\ Cambridge, MA 02138 \\ August 2004
}

The authors thank Sandy Black, Julie Cullen, Julia Darby, Tom Downes, Therese McGuire, Holger Sieg, and seminar participants at Northwestern University, the American Education Finance Association, and TAPES for many helpful suggestions. Jennifer Poole provided excellent research assistance. Gordon gratefully acknowledges support from the Spencer Foundation and the William and Flora Hewlett Foundation, through the Advanced Studies Fellowship Program at Brown University. Baicker gratefully acknowledges support from the Rockefeller Center at Dartmouth. The content of this paper is solely the responsibility of the authors. The views expressed herein are those of the author(s) and not necessarily those of the National Bureau of Economic Research.

(C2004 by Katherine Baicker and Nora Gordon. All rights reserved. Short sections of text, not to exceed two paragraphs, may be quoted without explicit permission provided that full credit, including (C) notice, is given to the source. 
The Effect of Mandated State Education Spending on Total Local Resources

Katherine Baicker and Nora Gordon

NBER Working Paper No. 10701

August 2004

JEL No. H0, H7, I2

\section{ABSTRACT}

Many states are under court-order to reduce local disparities in education spending. While a substantial body of literature suggests that these orders and the resulting school finance equalizations have increased the level and progressivity of state education spending, there is little evidence on the broader effects of such measures on the change in total resources available not only for schools, but for other local government programs as well. When states spend more on education, both state and local budget constraints change. We find that while mandated school finance equalizations increase both the level and progressivity of state spending on education, states finance the required increase in education spending in part by reducing their aid to localities for other programs. Local governments, in turn, respond to the increases in state taxation and spending by reducing both their own revenue-raising and their own spending on education and on other programs. Thus, while state education aid does increase total spending on education, it does so at the expense of drawing resources away from spending on programs like public welfare, highways, and hospitals. These findings provide insight into the effectiveness of using earmarked funds to achieve redistribution.

Katherine Baicker

Department of Economics

Dartmouth College

6106 Rockefeller Hall

Hanover, NH 03755

and NBER

katherine.baicker@dartmouth.edu

Nora Gordon

Department of Economics 0508

University of California, San Diego

La Jolla, CA 92093-0508

and NBER

negordon@ucsd.edu 


\section{INTRODUCTION}

Beginning with California’s landmark Serrano v. Priest case in 1971, states have moved towards increasingly redistributive school finance policies, with 22 states since having been ordered by their Supreme Courts to redistribute funds towards lower-income school districts. The main documented effect of these equalizations has been to increase the level and progressivity of state spending on schools. When states spend more on education, that changes both state and local budget constraints, and thus may affect many different spending and revenue decisions. States allocate funds to localities for many different programs, so mandated increases in state spending on education could result in offsetting reductions in funds provided to localities for other programs. Similarly, localities might react to these changes by changing their own revenue and spending decisions. The net effect of increased state spending on education on the total resources available to localities and spending on public goods may thus be quite different from the gross change in state education budgets. Given that localities receive thirty percent of their total revenues in the form of state intergovernmental grants, about 60 percent of which is earmarked for education, changes to this stream of funding are likely to have substantial effects on other aspects of state and local budgets. This is thus a particularly fertile area through which to explore the broader issues of the effectiveness of redistribution through earmarked funds and intergovernmental spillovers in the provision of public goods.

While a substantial body of research has documented that these state school finance equalization measures have increased both state spending on education and school budgets in low-income districts (but sometimes also reduced budgets in high-income districts), little attention has been paid to the potential offsetting reactions of state and local governments. Do states and localities act to negate any net change in mandated state education spending? Do 
school finance equalization measures increase the total resources available to low-income districts, or do they merely restrict the mix of grants they receive? Does total spending on public goods increase? What is the ultimate incidence of the mandate?

We examine the effect of mandated increases in state education spending on the distribution of public spending on a variety of programs - both education and non-education. We begin with an analysis of the impact of school finance equalizations (SFEs) on the level and progressivity of state intergovernmental aid to localities for education and for other program areas. Next, we analyze data at the local level to examine: (1) how states reallocate noneducation funds in response to mandated increases in education spending; (2) how local governments respond to changes in state education aid through their own revenue-raising behavior; and (3) how changes in state education aid affect local spending on education and other programs. We explore the factors that drive heterogeneity of local responses, including demographics, economic conditions, and political and legislative constraints. This approach allows us to consider the average and distributional consequences of increases in state education spending across different programs and different localities.

We use data on school finance equalizations and state and local revenues and expenditures in the 1980s and 1990s to explore these spillover effects. We find that both states and localities react to offset some of the changes in mandated state education spending. We find that mandated school finance equalizations do increase both the level and progressivity of state spending on education, but that states finance the required increase in education spending in part by reducing their aid to localities for other programs. While localities do get more money from the state for education after a court-ordered school finance equalization, for every dollar of increased state education aid they lose about 20 cents of state aid for other programs. Local 
governments respond to the increases in state taxation and spending by reducing their own revenue-raising, their own spending on education (thus blunting the effect of the increases in state education spending), and their spending on other programs.

Thus, while state education aid increases total spending on education, it does so at the expense of drawing resources away from spending on programs like public welfare, highways, and hospitals. Understanding these spillover effects is critical not only for understanding the full incidence of the mandated increases in state education aid, but also more broadly for evaluating the effectiveness of using earmarked funds to achieve redistribution. The effectiveness of redistribution through specific programs is limited by the ability of intervening levels of government to undo that redistribution and to redirect funds for other purposes, thus affecting the level, composition, and distribution of public spending.

\section{BACKGROUND ON SCHOOL SPENDING AND SCHOOL FinANCE EQUALIZATIONS}

Our central question is how state education aid to local school districts affects the total resources available to school districts and other local governments, and how much those local governments spend on programs, both education and non-education. Court-ordered school finance equalizations, in addition to being widely utilized policy instruments of independent interest, provide us with a source of externally-imposed variation in how states transfer funds to local school districts. Such variation is critical to identifying how receiving more or less state education aid affects other state aid received, local revenue generated, and levels of education and non-education program expenditures. For example, poorer areas within a state may (1) receive more education aid, (2) receive more state aid through other income-based progressive programs, and (3) raise less revenue themselves through income taxes - all because they have 
lower per capita income, not because any one causes the others. In order to abstract from these correlations (due to unobserved time-varying local conditions such as unmeasured income) and uncover a causal relationship, we need to use a source of exogenous variation in the amount of state education aid each locality receives. Previous research suggests that court-ordered school finance equalizations provide just such a shock to state education grants to school districts.

School finance equalization (SFE) measures have been adopted by many states voluntarily as well as under court order as a means to increase the resources available to students in poor school districts. States exhibit wide variation in the structure and details of their SFEs, and empirical and theoretical work has shown that these different ways of distributing state revenue to districts have significantly different effects on local responses and thus on school spending at the district level (see Downes and Shah (1996), Fernandez and Rogerson (1999), and Hoxby (2001)). We categorize SFEs following the work of Card and Payne (2002), updating information on SFEs after 1992 with information from Corcoran et al. (2003). In our analysis, we focus on SFEs in which state supreme courts ruled school financing systems unconstitutional and mandated reforms to the systems, consistent with Card and Payne's finding that that such court-ordered SFEs have the strongest effects on the distribution of state education revenue. We exclude court cases in which school finance systems were not overturned and instances in which state legislatures undertook SFE reforms of their own initiative, without judicial intervention (as these are more likely to be endogenously driven).

Our empirical strategy thus relies on the relatively exogenous nature of SFEs. While the literature on SFEs has centered far more on the effects of SFEs (discussed below) than on the circumstances which generate them, the existing evidence on whether pre-existing state conditions drive the timing of court orders suggests that court orders are largely independent of 
these conditions. Card and Payne explore the relationship between the progressivity of state education aid in 1977 and subsequent court-ordered school finance equalization. ${ }^{1}$ The progressivity of state education aid (measured by the effect of local income on state aid) looks strikingly similar for states that experienced (successful or unsuccessful) school finance litigation and those that did not: In states that ultimately received court orders between 1977 and 1992 , school districts received $\$ 1.37$ less (s.e. 0.21) in state aid per pupil for each additional $\$ 1000$ of median family income in the district in 1977; in states where court decisions upheld existing school finance systems, districts received \$1.28 less (s.e. 0.11); and in states where no court decisions were issued by 1992 , districts received $\$ 1.08$ less (s.e. 0.42). These results suggest that court-ordered SFEs did not result from systematically different pre-existing levels of progressivity in state aid.

Another piece of evidence supporting the exogenous nature of court-orders comes from the work of Figlio, Husted, and Kenny (2004). Their paper is an investigation of the contributors to within-state inequality in education revenue, rather than an examination of what causes SFEs, but they create a classification of state constitutional language that is useful for both purposes. ${ }^{2}$ They classify state constitutions along two dimensions: the strength of language supporting equity in education and the strength of language supporting adequacy in education. This language categorization (like Card and Payne's initial progressivity measure) appears uncorrelated with later SFE passage. ${ }^{3}$

\footnotetext{
${ }^{1}$ In Table 3 of their paper they estimate the effect of median family income in a school district on the state education aid it received. States distribute general education aid to school districts based largely on property wealth of the district, not income, and distribute aid for categorical programs based on eligible student counts by program area (for example, special education or bilingual education). The point of the Card and Payne approach is not to replicate the mechanism by which states distributed aid, but to characterize the ultimate incidence of that aid by district income level.

${ }^{2}$ Note that their classification has considerable but not complete overlap with that of McUsic (1991).

${ }^{3}$ These classifications are shown in Appendix Table 1.
} 
There is a large body of research (that we touch on only briefly here) that explores how SFEs have met their main goals of changing the amount and distribution of education spending - and, ultimately, changing the distribution of student outcomes. The primary finding from this literature is that SFEs do in fact change the amount of state aid to school districts sufficiently to alter both the distribution and mean level of local education spending. This results from changes in how states distribute aid, as well as in the amount states spend on education overall. Murray, Evans, and Schwab (1998) find that court-ordered SFE schemes reduced inequality in local education spending within states by up to one-third between 1972 and 1992. Card and Payne find that court-ordered SFEs increased the progressivity of state education aid to school districts from 1977 to 1992. In looking at a particularly severe SFE, Fischel (1989) finds that California's Serrano decision equalizing school spending led to the property tax limitation of Proposition 13 and subsequently to declines in spending on education.

Several recent papers (taking SFEs as exogenous) explore the ultimate impact of these SFE-induced changes in school spending on student outcomes. Card and Payne (2002) find that SFEs narrow the distribution of education spending, and correspondingly narrow the distribution of SAT scores. Hoxby (2001), considering the income and price effects of SFEs on a case-bycase basis, finds that some types of SFEs may reduce dropout rates for schools with the lowest spending prior to the SFE, while other types may increase private school attendance for districts facing extremely high marginal tax prices after the reform. Clark (2003) finds that while Kentucky's Education Reform Act did have a significant equalizing effect on school spending, it did not have an equalizing effect on student achievement. Our analysis of the spillover effect of changes in education spending may affect the interpretation of these findings: if increases in 
school spending were offset by decreases in other spending, those offsetting reductions could undermine gains in achievement that might otherwise be seen.

Little existing research has focused directly on the potential spillovers from SFEs to other parts of local budgets, although there is some indirect evidence. Cullen and Loeb (2001) look at how school districts in Michigan newly-constrained to increase their current education spending beyond their desired level of spending manipulate the categorization of their expenditures. For example, districts may have moved maintenance spending from capital to current accounts, allowing them to use SFE dollars for it. Gordon (2004) finds no significant total impact of federal compensatory education grants on instructional spending (the category of spending mandated by the grants) because of off-setting changes in state and local behavior. There is also some evidence on the effects that other narrow mandates have on total spending (both within and between jurisdictions) from outside the education literature. Baicker (2001) finds that states finance mandated increases in Medicaid spending primarily by cutting back on other public welfare spending that serves the same low-income population. There is also ample evidence of spillovers between jurisdictions - when one area spends more, neighboring areas adjust by spending more as well (see Case, Hines, and Rosen, 1993, and Baicker, 2004, for example).

Together, this literature suggests that examining the effect of mandated changes in education spending on education budgets alone would paint an incomplete picture of their distributional consequences. We examine the broader effects of mandated changes in education spending on the total resources available to local jurisdictions. 


\section{EMPIRICAL STRATEGY}

We wish to examine the effect of changes in state educational grants on the total resources available to and spent by different localities. We break down this question into three parts. $^{4}$ First, we ask how school finance equalizations (SFEs) change state spending and revenue. We examine aggregate state spending before and after SFE orders to verify that they actually increase state spending on education, and also explore the predictability of court-ordered SFEs. Second, we ask how SFEs change the progressivity of state spending, not only on education but on all other programs. We examine the relationship between a locality's income and the net revenue it receives from the state before and after SFEs. This question merits attention independently, but also provides an avenue to answer another set of questions. We ask, third, how (exogenous) changes in state spending on education affect localities' revenues from other sources and expenditures on other programs. We examine both the level and distributional effects of state education spending on local revenues and expenditures using SFEs to abstract from confounding changes in demographics and economic conditions. We also explore the demographic, economic, and political factors driving heterogeneous responses to changes in state education spending. In this section we detail our empirical strategy for answering these questions, and in the next section we describe our data.

\footnotetext{
${ }^{4}$ While we do not build a formal model of voter and legislature behavior here, our implicit framework is straightforward and similar in flavor to that of Baron and Ferejohn (1987 and 1989). The legislature makes allocative decisions which reflect the preferences of voters in the represented districts and the strategic behavior of representatives seeking re-election, given agenda-setting rules governing the legislative body. When the court mandates a school finance equalization, the basic intuition is that the legislature is no longer free to distribute education resources as they wish (they are now constrained in how they do this by the judicial mandate), so the distribution of funds designated for other purposes may change as well in order to return the distribution of net resources to an equilibrium state.
} 


\section{School Finance Equalizations and State Spending}

Following previous research, we begin with a simple analysis of the responses of aggregate state spending and revenue collection by estimating a regression of the following form:

$$
\text { revenue or expenditure }{ }_{s t}=\alpha_{s}+\beta_{t}+X_{s t} \Gamma+\delta S F E_{s t}+\varepsilon_{s t}
$$

where the dependent variable is a state revenue or expenditure category, in real per capita terms, $s$ indexes the state, and $t$ indexes time. We control for state and year fixed effects and state-level demographic characteristics (such as population, income, unemployment, and racial composition), and define SFE as a dummy variable equal to one if the state has had a court-order ruling its education finance system unconstitutional prior to that year. We begin with the aggregate state responses as a starting point for the broader distributional analysis. We need to know how states' spending and revenue are affected by SFEs: knowing that states increase education spending and property tax revenue collection following SFEs, for example, suggests potential responses in both local spending and revenue raising. $\delta$ shows the effect of the SFE on the average aggregate per capita state budget item.

We also use state-level data to explore the predictability of SFEs. We estimate:

$$
S F E_{s t}=\beta_{t}+X_{s t} \Gamma+\text { Constitutional Language } s_{s} \Lambda+\varepsilon_{s t}
$$

where "constitutional language" is a vector of the state constitution provisions for adequacy and equity of education developed by Figlio et al. and described above and $X_{s t}$ is a vector of timevarying state demographic characteristics. 


\section{The Distribution of State Education and Non-education Intergovernmental Grants}

Card and Payne demonstrate that SFEs make state spending on education more progressive, but we would like to know if there are offsetting changes in the progressivity of other state grants to localities. ${ }^{5}$ Adapting Card and Payne's methodology, we next characterize a school finance regime's progressivity by the extent to which a locality's per capita state education revenue is negatively correlated with its median family income. We then analyze the extent to which states operating under court-ordered school finance equalizations change the progressivity of their distribution of education aid and non-education aid to localities. We thus estimate:

$$
\begin{aligned}
&\left(\text { educ) rev from } \text { state }_{i t}=\right. \alpha_{i}+\beta_{t}+X_{i t} \Gamma+\delta_{1} \text { median fam income } \\
&+ \\
& \delta_{2} S F E_{s t}+\delta_{3} S F E_{s t}{ }_{\text {st }} \text { relative fam income } \\
& i
\end{aligned}
$$

where $i$ indexes the county-level observation, $t$ indexes time, and $X$ is a vector of time-varying county-level demographics (including population, employment rates, racial composition, and urbanicity). While local median family income is time-varying, relative family income is measured in standard deviations from the state-year average in 1982 (and is therefore constant for a given county over time). SFE indicates that $i$ 's state has received a court-order to equalize school spending at any time before the current year. $\delta_{3}$ thus tells us the change in progressivity of state grants to localities under the post-SFE regime.

\section{Changes in Local Spending and Revenues}

Finally, we want to know the effect of exogenous changes in state education expenditures on other categories of local spending and revenue-raising. We estimate:

\footnotetext{
${ }^{5}$ Another avenue through which states might respond is changing the progressivity of non-intergovernmental spending and revenues - such as the progressivity of income taxes or the size of low-income assistance programs. We will explore these mechanisms in future research.
} 
revenue or expenditure ${ }_{i t}=\alpha_{i}+\beta_{t}+X_{i t} \Gamma+\delta$ educ revenue from state ${ }_{i t}+\varepsilon_{i t}$

where the dependent variable is local revenue from various sources (including that raised locally and that received through intergovernmental transfers) and expenditure on different programs (including education and non-education). $i$ indexes counties (including, as discussed below, all sub-units of government contained within a county, such as school districts and towns), $s$ indexes states, and $t$ indexes time. Demographic covariates $X$ again include county-area population, employment/population ratio, median family income (changing over time), percent black, percent Hispanic, percent poor, and percent urban.

Clearly if we were to estimate this regression via least squares, the coefficient $\delta$ would capture not only state reactions to being forced to increase education grants, but also underlying economic conditions, the state's overall propensity to redistribute, demographic conditions, etc. not a causal connection between how much aid the state gives a locality for education and how much the state gives that area for other programs or how much the locality spends. Wealthy areas will be eligible for fewer categorical funds for poverty programs, for example, and will also receive fewer state education dollars per pupil if the state school finance system is progressive. This does not imply that receiving lower amounts of education aid causes them to receive less revenue targeted for public welfare programs from the state. While we control for many demographic variables (and county and time fixed effects), we still do not have access to the full set of administrative data used in allocating categorical grants, nor to all data likely to influence local demand for public goods.

In order to find out whether changes in state education revenue are offset by changes in other state aid and how such changes affect local spending and revenue choices, we need to use an exogenous source of variation in school spending. Fortunately, as previous literature suggests 
and as we demonstrate below, the school finance equalization measures discussed above provide just such a source of variation. By focusing on the change in state education revenue to local areas that is mandated by the imposition of a court-ordered SFE, we can see if a shock to education revenue is offset by changes in other resources available to the area, and how it affects local spending decisions.

We implement this strategy via two-stage least squares instrumental variables estimation, and later show that the results are robust under several alternate specifications. The first stage isolates the exogenous portion of changes in state education revenue received by county areas by estimating state aid to localities based on local demographics $X$, county and time fixed effects, and whether a court-ordered SFE is in place. Our first stage is thus:

$$
\text { educ rev from state } \text { fit }=\alpha_{i}+\beta_{t}+X_{i t} \Gamma+\delta_{1} S F E_{s t}+\varepsilon_{i t}
$$

We then estimate equation (4) via two-stage least squares, using the predicted education revenue from the state from equation (5).

\section{Heterogeneity of Responses}

Localities may respond differently to these changes, however, based on factors such as demographics, legal environment, or income. We begin by examining whether high- and lowincome districts respond differently. We expect heterogeneity of response by income-level to the extent that median income is correlated with demand for education spending and with the heterogeneous effects of SFEs within states. ${ }^{6}$ We include the interaction of relative family income (again, measured in standard deviations from the state-year average in 1982) with state education grants:

\footnotetext{
${ }^{6}$ While we treat SFEs uniformly within states, their effects are actually heterogeneous: as Hoxby shows, the marginal "tax price" of raising local revenue for school spending can vary as much within states as between them. This within-state heterogeneity typically is based on the property wealth of the district, not median income.
} 


$$
\begin{aligned}
\text { rev or expenditure }_{i t}= & \alpha_{i}+\beta_{t}+X_{i t} \Gamma+\delta_{1} \text { educ rev from state }{ }_{i t} \\
& +\delta_{2} \text { educ rev from state }{ }_{i t}{ }^{*} \text { relative income } e_{i}+\varepsilon_{i t}
\end{aligned}
$$

Here we use the SFE variable and its interaction with relative income (similar to equation (3)) as instruments in the two first stages. (Note that relative income is not included as a control apart from the interaction because it is fixed over time and is therefore captured by the county-area fixed effect. Median income, changing over time, is included as a covariate in $X$.) We then allow income to affect responses asymmetrically (still continuously), including relative income for those counties above the state mean and below the mean separately:

$$
\begin{aligned}
\text { rev or expenditure }{ }_{i t}= & \alpha_{i}+\beta_{t}+X_{i t} \Gamma+\delta_{1} \text { educ rev from state }{ }_{i t}^{\Lambda} \\
& +\delta_{2}{ }_{i t} \text { educ rev from state } *(\text { rel.inc if above mean })_{i} \\
& +\delta_{3}{ }_{i t} \text { educ rev from state } *(\text { rel.inc if below mean })_{i}+\varepsilon_{i t}
\end{aligned}
$$

These specifications allow us to examine more fully the role that income has on the heterogeneity of local responses to changes in state spending on education.

There are other dimensions along which local responses may vary systematically. We include analysis of the effects of six other factors (tax and expenditure limits, home ownership, the size of local government relative to state government, poverty rates, dependent versus independent school district structure, and the black population share) on the responses of localities. The presence of tax and expenditure limits may constrain the choices available to states and local jurisdictions. Home ownership rates may affect the distribution of costs and benefits of different tax and expenditure bundles as the quality of local public goods is capitalized into home prices. Localities in states where local government plays a larger role relative to state government may have differential ability to offset changes in state behavior. 
Funds in school districts that rely on a parent local jurisdiction for funding may be more susceptible to redirection. We allow the effect of mandated changes in state education revenues to vary based on each of these factors in turn.

\section{DATA}

The goal of this analysis is to determine the effect of mandated changes in school spending on the total revenues available to local governments, the composition of those revenues, and how those revenues are allocated across expenditure programs. If states become constrained in how they distribute education aid to school districts, does this affect how the level and progressivity of their spending on all programs? How do localities change their spending and revenues in response to these changes? How does local income affect these responses? We thus need data on state local revenue and expenditures on different categories, the presence of a court-ordered SFE, and controls for local demographics and economic conditions.

\section{The County-area Unit of Observation}

School districts are distinct governmental units, and state education aid typically flows directly to them rather than through other local governments. ${ }^{7}$ Because school districts by definition spend only on education, we must look to the local governments with which they are geographically coterminous if we wish to identify the effects of SFEs on revenues and expenditures not related to education. Therefore, some type of linkage from school districts to local governments is necessary for investigating effects of state education aid on intergovernmental revenues earmarked for and spending on non-education programs.

\footnotetext{
${ }^{7}$ This is true for independent school districts, which comprise about 90 percent of the districts in the United States. Dependent school districts do not collect revenue themselves and instead rely on local parent governments for their financial support. Our county-area aggregation approach allows consistent treatment of both types of districts.
} 
The mapping of school districts to other local governments varies both across and within states: school districts may share full or partial boundaries with counties or municipalities. Some school districts contain multiple municipalities, and some cities contain multiple school districts. Additionally, the degree to which different types of local governments (for example, counties versus cities) take responsibility for non-education expenditures differs by state. For these reasons, we use the Census of Government's county-area unit of observation, which aggregates up revenues and expenditures for all governments within a given county. This typically includes the county government itself, ${ }^{8}$ all municipal and/or township governments located within the county, all school districts in the county, and any special districts in the county. ${ }^{9}$ This unit of observation suits our needs by both linking school district finances to geographically coterminous other local government finances, and providing a unit of observation that is consistent across states despite state-level variation in the responsibilities of different levels of local governments.

The drawback of this aggregation approach is that we do not capture changes in the distribution of state aid within county areas. Most states have multiple school districts in a given county, so our approach captures only part of the redistribution induced by the SFE (i.e., if one school district in a county benefits from SFE while another suffers, we only observe the net effect at the county level). As we show below, even at this aggregated level we find strong effects of SFEs on the distribution of state education aid. For our purposes, this drawback of

\footnotetext{
${ }^{8}$ Connecticut and Rhode Island do not have county governments recognized by the Census of Governments. Because their non-county local government finances can still be aggregated up to the county level, they are included in our data.

${ }^{9}$ Special districts are districts formed for special purposes, independent of other local governments. The most common functions of special districts relate to natural resource management, fire protection, water supply, housing and community development, and sewerage.
} 
aggregation is clearly outweighed by the advantage of a consistent way to link changes in each area's education resources to changes in its other resources.

\section{County-area Revenue and Expenditure Data}

Information on state and local revenues and expenditures is available from the Census of Government Finances, collected by the Bureau of the Census. The Census is collected every 5 years, in years ending in 2 and 7, and represents most governmental units. We use, at different points, both the state and county-area files. All county-area revenue and expenditure dependent variables are expressed in per capita terms in thousands of real 2000 dollars, and are summarized in Table $1 .{ }^{10}$ Our approach compares county-area budgets over time, so we control for countyarea fixed effects as well as time-varying county-area demographics and economic conditions. ${ }^{11}$

We analyze primarily major revenue and expenditure categories, and for consistency we construct total revenue and direct expenditure by aggregating up spending and revenues from these categories. ${ }^{12}$ The totals presented here are therefore smaller than actual totals reported in the Census of Governments data and education spending as a share of our total spending measure is a larger ratio than education spending as a share of the reported Census of Governments total. Our totals are, however, consistently constructed over time to contain the largest sources of revenues and expenditures. Real county-area revenues per capita in our sample grew from $\$ 1565$ on average in 1982 to $\$ 2272$ in 1997 . Mean real per capita direct expenditures (excluding intergovernmental expenditures) grew from $\$ 1345$ in 1982 to $\$ 1919$ in 1997 . Most localities,

\footnotetext{
${ }^{10}$ Unfortunately these data are notoriously noisy. We conservatively trim obvious miscodings (including, for example, an isolated jump in spending by a factor of 100 in one year), but results are not sensitive to this procedure. ${ }^{11}$ We do not currently model these demographics as endogenous to school finance reform, though some empirical evidence suggests that SFEs impact residential location decisions (see Aronson, 1999). Results excluding these demographics as controls are quite similar.

${ }^{12}$ Reporting of totals and netting out of intra-county-area transfers changed substantially between the 1980s and the 1990s, so we focus primarily on direct expenditures, which were reported consistently and comprise the bulk of all expenditures.
} 
unlike the federal government, have limited ability to run deficits so it is not surprising that revenues exceed expenditures on average. In 1997, elementary and secondary education expenditures comprised over 60 percent of our measure of total direct spending by local governments. Other major categories of expenditures include hospitals, highways, police, and welfare. County-areas received just over 40 percent of their revenues as intergovernmental grants from the state, with three-quarters of those earmarked for education - so changes to this funding stream are likely to have a substantial impact on other aspects of state and local budgets.

\section{Classification of School Finance Equalizations}

Table 2 lists the states and years, through 1997, in which state supreme courts ruled school financing systems unconstitutional and mandated reforms to the systems (following Card and Payne, and Corcoran et al). ${ }^{13}$ It reveals considerable useful variation in the timing of school finance equalizations: from 1982 to 1997,14 states received court orders to reform their school finance systems. ${ }^{14}$ From the data in our Table 2, we create a dichotomous SFE variable indicating if the state has had its school finance regime ruled unconstitutional in the past or in that year. ${ }^{15}$

\section{Covariates}

We control for county-level population, employment/population ratio, relative family income, percent black, percent Hispanic, percent poor, and percent urban in all specifications. We obtain these variables from the Area Resource File and the Census Bureau.

\footnotetext{
${ }^{13}$ For lists of cases in which state supreme courts upheld school finance systems or in which reform was legislatively rather than judicially induced, see Card and Payne, Table 1.

${ }^{14}$ Before 1982, eight states had SFEs. Five of the states already under court order in 1982 experienced new court rulings requiring SFE between 1982 and 1997.

${ }^{15}$ The SFE variable turns from 0 to 1 when such a ruling occurs, and then stays at 1.
} 
We interact state education aid, the variable of interest, with a number of demographic and institutional variables when exploring the heterogeneity of local responses to state aid. The demographic variables are county level home-ownership, poverty rate, and black population share. For each of these variables, we calculate the median at the state level in 1982 (weighted by population). We then create dummy variables equal to one if the county has a higher population share (of homeowners, the poor, or blacks) than the state. These demographic variables are from the Area Resource File.

We also estimate the interaction of changes in state aid with three variables that capture the institutional environment in each state: the presence of tax or expenditure limits in the state (from the Advisory Commission on Intergovernmental Relations), the ratio of local revenue collected in the state to revenue collected by the state itself (from the Census of Governments), and the presence of any dependent school districts in the county (from the Common Core of Data). Each variable is coded as a dummy based on the value in 1982, the beginning of our sample. $^{16}$

\section{RESUlts}

We set out now to answer three questions: First, how do school finance equalizations change state spending and revenue? Second, how do they change the progressivity of state spending, not only on education but on all other programs? Third, how do these changes in state spending affect localities' revenues from other sources and expenditures on other programs?

\footnotetext{
${ }^{16}$ We use the ratio of local revenue collected in the state in 1982 to state revenue collected in 1982 to construct a dummy variable equal to one if the county was in a state with a higher ratio of local to state revenue than the population-weighted national average.
} 


\section{The Effect of SFEs on State Spending and Revenues}

We present results on aggregate state responses to school finance equalizations, from the estimation of equation (1), in Table 3. Estimating the regression at the state level with only four years of data unsurprisingly yields mainly imprecisely estimated and statistically insignificant results. We estimate insignificant but positive effects of SFE on elementary-secondary spending (both total and intergovernmental) and spending on all intergovernmental grants. The estimation also yields positive and insignificant point estimates on total revenue and two of its major components, sales tax revenue and revenue from charges, although the estimated effect on income tax revenue is negative (again, insignificantly so). These results are generally consistent with those of Murray, Evans, and Schwab, who find that school finance equalizations typically are not self-financing, and that states finance them through increased revenue collection rather than through cuts in other programs. It is also worth noting that the increases in state spending come not just through education spending (which is primarily intergovernmental), but also perhaps through public welfare spending - although none of these is significant at the 5 percent level.

This state-level data also gives us an opportunity to explore the predictability of SFEs. Are certain states more likely to be under court order to increase (the equity of) their school spending? We estimate equation (2) to gauge the exogeneity of the timing of court-ordered SFEs. The adjusted $\mathrm{R}^{2}$ from this regression is 0.037 , corroborating the findings of previous research that the presence of SFEs is largely unpredictable. Results from a Probit, rather than this linear probability model, predict the presence of SFEs equally badly, with a pseudo- $\mathrm{R}^{2}$ of 0.058 . 


\section{The Progressivity of State Education and Non-Education Grants}

Table 4 shows the results from estimation of equation (3). Court-ordered SFEs do serve to redistribute education revenue from the state towards poorer counties, as evidenced by the negative and statistically significant coefficient on the $S F E^{*}$ relative family income term. The positive and significant coefficient on the $S F E$ term reveals that equalizations also increase the average level of state education aid to local districts. SFEs prompt much more minor, though also statistically significant, increases in the progressivity of state intergovernmental revenue to localities outside of education; they also lower the average amount of such aid. On net, SFEs increase the level of state aid to localities overall (for education and other programs combined), and do so progressively.

\section{Level and Distribution of Local Spending and Revenues}

We next examine the effect of changes in state education spending on local revenues (including revenues to localities from the state for education, other revenues from the state, and locally-raised revenues) and expenditures (including education and non-education spending). We begin by estimating equation (4) via OLS. These results are shown in Table 5: these (naïve) regressions suggest that every dollar of state intergovernmental expenditure on education results in an offsetting reduction in total local revenue-raising of about 41 cents. Almost the entire net increase in revenues the locality sees (64 cents) goes straight to education spending, which increases by 53 cents. Spending on several other categories does not change statistically significantly; in those categories for which it does, the magnitude of the changes are extremely small (always less than a two-cent increase or decrease in spending in response to a one-dollar increase in education revenue). 
Because state and local spending decisions are based on local economic conditions, demographics, and preferences, the OLS results may not capture the causal relationship we would like to identify. We use the presence of court-ordered school finance equalization measures, as described above, to capture exogenous changes in the revenues localities receive from the state for education. We next estimate equation (4) using the presence of school finance equalizations to instrument for state intergovernmental spending on education. ${ }^{17}$ Table 6 shows the results of the separate second-stage estimation of the average effect of SFE-driven state education spending on different local budget categories. As these estimates show, there is no statistically significant net effect of SFE-induced state education aid on total county-area revenue, as increases in education aid are canceled out by both state intergovernmental aid for non-education programs and own-source revenue declines. For each dollar of state education aid, total state aid to localities rises by only $\$ 0.78$ (different from 1 with $\mathrm{p}=.007$ ). The estimates of the effect on other state intergovernmental aid categories show that reductions in state aid to localities for highways, welfare, and health and hospitals explain nearly all of the $\$ 0.22$ crowdout of other state funds. At the mean, the implied elasticity of total state grants with respect to changes in state education grants is more than .5. As we would expect, there is no corresponding reduction in federal intergovernmental revenues to localities. The other main change crowding out the increase in state education aid is a decline in locally-generated revenue of $\$ 0.29$, although this is not statistically significant. ${ }^{18}$

\footnotetext{
${ }^{17}$ The first column of Table 4 shows the first stage estimate of the effect of SFEs on state education grants to localities. An alternate approach would be to use propensity score matching to match observations with SFEs to those without, and then use this score to estimate the average treatment effect of an SFE on state education grants. This estimate yields very similar results - a point estimate of .065 (standard error .006).

${ }^{18}$ This includes taxes (such as income, property, and sales taxes) and charges (such as hospital charges, tuition charges (primarily for higher education), sewerage, and highway and transportation charges). There is some heterogeneity between states in how revenues are labeled.
} 
On the expenditure side, we see that while education expenditures go up (with a coefficient of $\$ 0.86$ that is significantly different from zero and not from one), expenditures on several other categories go down - in particular hospitals, highways, health and public welfare. ${ }^{19}$ In fact, these decline by so much that there is no significant net effect of the state education aid on total direct expenditures.

Table 7 tests the robustness of these results to alternate specifications. First, we might be concerned that spending and revenue trends over time could be quite different for poor counties and rich counties. We include time dummies interacted with an indicator for counties that are poorer than the median county in their state in the initial period to test for this possibility. (Note that IV results omitting both this and all other covariates (Wald estimator) are virtually identical.) Second, we show the GLS random effects estimates rather than the fixed effects estimator. $^{20}$ Third, we show the propensity score matching estimator. ${ }^{21}$ While some of these estimates are imprecise, in each case the results are quite consistent.

\section{Heterogeneity of State Responses}

Next, we consider several different potential sources of heterogeneity of local responses. While Table 6 shows us the effect of SFE-driven state education spending on the average locality, Table 8 presents estimates of equation (6), where both the SFE instrument and the (endogenous) state spending on education are interacted with the relative family income measure. As these estimates show, higher-income localities see a greater crowding out of other state revenue for each dollar they might get of state education aid. For example, a county with

\footnotetext{
${ }^{19}$ There may be bureaucratic constraints on localities' ability to transfer funds between programs, since different legislative and political entities often control spending on schools versus other programs within the county area. (See, for example, the substantial literature on the "flypaper effect" and "Leviathan" government.)

${ }^{20}$ The county-area jurisdictions we analyze are the population of counties in the US, not a sample, and are fixed over time, so the fixed effects estimator is likely preferable.

${ }^{21}$ We match observations based on the same set of covariates, and include the propensity and propensity ${ }^{2}$ in the second stage estimation.
} 
income one standard deviation above the state average would see other state aid reduced by 46 cents for each dollar of education aid, while a county at the mean would see only a 34 cent reduction - this pattern thus reinforces the progressivity of changes in education spending. On the expenditure side, higher-income (higher spending) counties are more likely to cut back on some other program expenditures as their education revenues (and expenditures) rise. This is true and statistically significant for direct spending overall; while the effects on many of the individual expenditure categories are not statistically significant, the coefficients are systematically negative. School finance equalizations and the changes in state spending they create thus have distributional implications not only for average spending across different budget categories, but also on the mix of revenues and expenditures used by localities with different income. These results are also consistent with Hoxby's finding that SFEs have differential effects on localities with different incomes.

In Table 8 we also show the results of equation (7), which allows the effect of income to be continuous but asymmetric, to see if income affects the responses of richer counties differently from the way it affects poorer counties. ${ }^{22}$ We report the probability that income differentially affects the responses of counties above and below the median income for their state in 1982 (or that $\delta_{2}=\delta_{3}$ from equation (7)). It appears that high income counties see a greater offsetting reduction in both total expenditures and total revenues as their income rises (the first column in each panel). The offsetting reduction in revenues seems to come, again, primarily from reductions in own-source local revenue. There seem to be greater reductions in several

\footnotetext{
${ }^{22}$ Gamkhar and Oates look for asymmetries in state local responses to changes in federal grants, but find similar responses to increases and decreases in grants.
} 
expenditure categories, although the standard errors are too large in most cases to conclude that responses are asymmetric. $^{23}$

Table 9 shows the results of regressions with six different interaction terms checking for heterogeneity of response by demographic and institutional characteristics. For each type of characteristic, we present results from four separate regressions (dependent variables label the columns). We begin by allowing local responses to state education aid to vary based on the presence of local tax or expenditure limits in the state. Consistent with previous analyses of California's reaction to Proposition 13, states with tax and expenditure limits in place in 1982 see significantly more local off-setting of state increases in education spending (resulting in smaller increases in total education spending). We do not detect a statistically significant differential effect on locally-raised revenue, but the coefficient is negative and similar in magnitude to that predicting total intergovernmental revenue from the state, consistent with local and state revenue serving as substitutes for one another.

Second, we consider the effect of above-average home-ownership rates. Responses to state education aid are not significantly different when home-ownership rates are higher, and for most budget categories the magnitude of the coefficient on the interaction term is relatively close to zero. Third, in the far right top panel of Table 9, we present results showing how responses to state education aid vary in states where local revenue is more important (relative to state revenue). ${ }^{24}$ County-areas in states with more local control get a significantly greater boost to total state intergovernmental revenue from state education aid. These results are consistent with the idea that states that have a smaller role in revenue-raising do less off-setting of mandated

\footnotetext{
${ }^{23}$ There may be even more income heterogeneity, but unfortunately, data do not allow a finer degree of decomposition (for example, into income quartiles).

${ }^{24}$ Again, we define this variable in 1982, so changes in state versus local revenue collection attributable to our identifying variation in SFEs between 1982 to 1997 are not incorporated in this "more local control" variable.
} 
increases in education spending. (Clearly, states with more local control by this definition may differ along other dimensions that affect spending as well (such as voter preferences). These results should thus be interpreted as descriptive rather than causal.)

In the bottom panel of Table 9, we next show results on heterogeneity of response by whether counties have higher poverty rates than the state average (again, in 1982). These results are consistent with the results by income in Table 8, which showed higher income counties experience more offsetting results from other state aid and total spending; here we see that counties with higher poverty rates experience less offsetting along these dimensions. Fifth, we examine the differential impact of state education aid on county-level revenues and expenditures for counties with and without dependent school districts. The only significant response we see

here is for total expenditures, which is consistent with the fiscal dependence of these districts facilitating the process of their parent governments moving state aid earmarked for schools into other budget categories. Last, we examine the role that the racial composition of the countyareas plays in its response to changes in state education aid. None of these coefficients is significantly different from zero. Overall, while these interactions provide some intriguing hints about the underlying process governing local responses to changes in state education spending, none seems decisive in driving the heterogeneity of state responses.

\section{CONCLUSION}

School finance equalizations are increasingly being used as a policy tool to improve outcomes for poor children. The existing literature shows that these equalizations have had at least some success in redistributing state education dollars towards children in school districts with lower property wealth, but how redistributive these programs are and how they ultimately 
affect child outcomes depend critically on any resulting changes in other public expenditure programs. While it is difficult to design systems that prevent any local "undoing" of redistribution from higher-level jurisdictions (or "undoing" of net redistribution by those higherlevel jurisdictions themselves), understanding the magnitude and impact of such responses should inform policy design. Changes in state intergovernmental spending on education provide valuable insight into these spillovers - both because of the prominence of direct and intergovernmental education spending in state and local budgets and because of the policy experiments that mandated changes in the level and distribution of state spending.

We find that states did change their spending patterns in a way that partially offset the mandated increase in their education spending (although not in a way that diminished their progressivity). Each dollar of increased education funding a locality received from the state resulted in an average decline in funds from the state for other purposes of about 20 cents. Localities, in turn, reacted to the increased state revenue-raising and spending by cutting back on their own revenue-raising and their spending on both education and other programs. The greatest impacts were on hospitals, highways, and welfare, but there were also significant declines in spending on police, public health, fire protection, and public buildings. Thus, while mandated increases in state education aid did increase total spending on education, they did so at the expense of drawing resources away from spending on other programs. These effects were greater in higher-income counties.

Researchers need to incorporate the effect of these offsetting responses when they analyze the effects of mandated education spending changes on student outcomes, such as achievement test scores, high school dropout rates, and college attendance. Changes in these outcomes reflect not only the changes in education spending but also changes in other resources 
which are inputs into those same student outcomes. If, for example, high school dropout rates are unchanged with increased spending from school finance equalizations, a naïve interpretation would suggest that "money doesn't matter" for education. If, in fact, students are simultaneously experiencing a decline in programs such as community policing, summer camps, and vaccination campaigns, both educational resources and other resources could have mattered for student outcomes very much indeed.

More broadly, these results have strong implications for redistribution policy in a federal system - both across programs and between localities. The effectiveness of redistribution through specific programs is limited by the ability of intervening levels of government to undo that redistribution and to redirect funds for other purposes. State governments may change both the composition of funding that each locality receives and the division of resources between localities in response to mandated changes in spending on certain programs or to certain jurisdictions. Local jurisdictions, in turn, may also change the level and composition of their own spending. Policy-makers must decide whether their goal is to change the level, distribution, or composition of public spending, and then anticipate the potentially off-setting reactions of intervening levels of government.

These findings also prompt many new questions - both for education policy and for public spending more generally. While we have shown that school finance equalizations on average have important spillover effects on other revenues and expenditures, the details of those equalizations, the policy environments in which they occur (such as under different school accountability measures or property tax limits), and how states raise revenue likely matter significantly in determining the nature of state and local responses. ${ }^{25}$ Furthermore, while we

\footnotetext{
${ }^{25}$ In future work, we will characterize school finance regimes by relevant parameters of their foundation or guaranteed tax revenue plans, as appropriate, to better identify changes in lump-sum grants and changes in tax prices
} 
have documented particular spillovers that result from policies aimed at redistribution through narrow programs, there are several other potential channels through which spillovers may occur. First, future work will couple analysis of the progressivity of state education spending with a parallel analysis of the progressivity of state and local raising-revenue - since changes in revenue patterns may change the net distribution of resources across residents of different localities. Second, changes in state education financing schemes or other changes to how local public goods are financed may affect local residential sorting and property values. Incorporating these broader spillover effects will further refine our understanding of the effectiveness not only of school finance equalization measures but of targeted redistribution policy in a federal system.

facing local governments. Again, changes in those parameters induced by court rulings can identify shifts in local responses that are not correlated with changes in state-level preferences for redistribution or education spending. 


\section{REFERENCES}

Aaronson, Daniel. "The Effect of School Finance Reform on Population Heterogeneity," National Tax Journal 52 (1), March 1999, pp. 5-29.

Advisory Commission on Intergovernmental Relations, Significant Features of Fiscal Federalism, Washington DC, various years.

Baicker, Katherine. "Government Decision-Making and the Incidence of Federal Mandates," Journal of Public Economics, 82 (2001).

Baicker, Katherine. "The Spillover Effects of State Spending." Journal of Public Economics, forthcoming (2004).

Card, David and A. Abigail Payne. "School Finance Reform, the Distribution of School Spending, and the Distribution of Student Test Scores," Journal of Public Economics, 83 (2002).

Case, Anne C., James R. Hines, and Harvey S. Rosen. "Budget Spillovers and Fiscal Policy Interdependence: Evidence from the States," Journal of Public Economics 52(3) (1993), 285-307.

Clark, Melissa A. "Education Reform, Redistribution, and Student Achievement: Evidence from the Kentucky Education Reform Act," manuscript, October 2003.

Corcoran, Sean, William N. Evans, et al. "The Changing Distribution of Education Finance: 1972-1997," manuscript, January, 2003.

Cullen, Julie Berry and Susanna Loeb. "Fiscal Substitution in the Context of School Finance Reform," manuscript, 2000.

Downes, Thomas A. and Shah, Mona P. "The Effect of School Finance Reforms on the Level and Growth of Per Pupil Expenditures.” Mimeo, Northwestern University, April 1995.

Fernandez, Raquel and Richard Rogerson. "Education Finance Reform and Investment in Human Capital: Lessons from California," Journal of Public Economics, 74 (1999), 327-350.

Figlio, David N., Thomas A. Husted and Lawrence W. Kenny. "Political Economy of the Inequality in School Spending," Journal of Urban Economics, 55 (2004), 338-349.

Fischel, William. “Did Serrano Cause Proposition 13?” National Tax Journal, 42, December 1989, pp. 465-474.

Gamkhar, Shama and Wallace E. Oates. "Asymmetries in the Response to Increases and Decreases in Intergovernmental Grants: Some Empirical Findings," National Tax Journal, 49 (4), December 1996, pp 501-12.

Gordon, Nora. "Do Federal Grants Boost School Spending? Evidence from Title I," Journal of Public Economics, Vol. 88/9-10 (2004), 1771-1792.

Hoxby, Caroline M. “All School Finance Equalizations Are Not Created Equal,” Quarterly Journal of Economics 16 (4), November 2001.

McUsic, Molly. "The Use of Education Clauses in School Finance Reform Litigation," Harvard Journal on Legislation 28 (1991), 307-340.

Minorini, Paul and Stephen Sugarman. "School Finance Litigation in the Name of Educational Equity: Its Evolution, Impact and Future." In Helen Ladd and Rosemary Chalk, eds. Equity and Adequacy in School Finance (pp. 34-71). Washington, DC: National Academy Press, 1999. 
Murray, Sheila, William N. Evans, and Robert Schwab. "Education Finance Reform and the Distribution of Education Resources," American Economic Review, 88, September 1998, 789-812.

National Center for Health Workforce Analysis, Area Resource File, Department of Health and Human Services, 2003.

U.S. Bureau of the Census, Census of Governments and County and City Data Book, various years. 
Table A.1

Constitutional language and court rulings of unconstitutional school finance systems, through 1997

Panel 1: States with court-ordered school finance equalizations through 1997

\begin{tabular}{|l|l|l|l|}
\hline & Constitutional language on equity & High \\
\hline $\begin{array}{l}\text { Constitutional } \\
\text { language on } \\
\text { adequacy }\end{array}$ & Low & Medium & NC \\
\hline Low & $\begin{array}{l}\text { AL, AR, CA, CT, } \\
\text { KS, KY, MA, MO, } \\
\text { NH, TN, VT }\end{array}$ & WI & \\
\hline Medium & NJ, OH, RI, WV & AZ, TX, WY & MT \\
\hline High & & WA & (n) \\
\hline
\end{tabular}

Panel 2: States without court-ordered school finance equalizations through 1997

\begin{tabular}{|l|l|l|l|}
\hline \multicolumn{4}{|l|}{ Constitutional language on equity } \\
\hline $\begin{array}{l}\text { Constitutional } \\
\text { language on } \\
\text { adequacy }\end{array}$ & Low & Medium & High \\
\hline Low & $\begin{array}{l}\text { DE, IA, ME, MI, } \\
\text { MS, NE, NY, OK, } \\
\text { SC, UT }\end{array}$ & IN, ND, NV, OR & \\
\hline Medium & GA, MD, PA & $\begin{array}{l}\text { CO, FL, ID, MN, } \\
\text { SD }\end{array}$ & NM \\
\hline High & IL, VA & & LA \\
\hline
\end{tabular}

Sources: Card and Payne (2002), Corcoran et al (2003), and Figlio et al (2004). 
Table 1: Summary Statistics

\begin{tabular}{|c|c|c|c|c|c|c|c|c|}
\hline & \multicolumn{2}{|c|}{1982} & \multicolumn{2}{|c|}{1987} & \multicolumn{2}{|c|}{1992} & \multicolumn{2}{|c|}{1997} \\
\hline & Mean & Std Dev & Mean & Std Dev & Mean & Std Dev & Mean & Std Dev \\
\hline \multicolumn{9}{|l|}{ Revenues (\$thous per cap) } \\
\hline Total & 1.57 & 0.63 & 1.85 & 0.74 & 2.03 & 0.79 & 2.27 & 0.93 \\
\hline Federal Intergov. & 0.06 & 0.10 & 0.07 & 0.09 & 0.05 & 0.08 & 0.06 & 0.08 \\
\hline State Intergov. & 0.65 & 0.29 & 0.76 & 0.33 & 0.86 & 0.36 & 0.96 & 0.39 \\
\hline State Intergov - Education & 0.46 & 0.19 & 0.55 & 0.23 & 0.63 & 0.26 & 0.72 & 0.25 \\
\hline State Intergov - Highways & 0.06 & 0.08 & 0.07 & 0.10 & 0.07 & 0.11 & 0.08 & 0.11 \\
\hline State Intergov - Pub Welfare & 0.03 & 0.06 & 0.03 & 0.07 & 0.04 & 0.08 & 0.03 & 0.07 \\
\hline State Intergov - Hlth \& Hosp & 0.01 & 0.02 & 0.01 & 0.03 & 0.02 & 0.04 & 0.02 & 0.04 \\
\hline Own Sources & 1.10 & 0.67 & 1.29 & 0.84 & 1.30 & 0.81 & 1.44 & 0.92 \\
\hline \multicolumn{9}{|l|}{ Expenditures (\$thous per cap) } \\
\hline Total - Direct & 1.36 & 0.52 & 1.63 & 0.62 & 1.77 & 0.68 & 1.93 & 0.72 \\
\hline Education & 0.84 & 0.30 & 1.00 & 0.35 & 1.10 & 0.38 & 1.21 & 0.39 \\
\hline Public Welfare & 0.04 & 0.08 & 0.05 & 0.10 & 0.06 & 0.11 & 0.06 & 0.11 \\
\hline Hospitals & 0.14 & 0.21 & 0.15 & 0.25 & 0.17 & 0.29 & 0.18 & 0.35 \\
\hline Health & 0.03 & 0.04 & 0.03 & 0.04 & 0.04 & 0.06 & 0.05 & 0.08 \\
\hline Highways & 0.16 & 0.15 & 0.18 & 0.18 & 0.17 & 0.15 & 0.18 & 0.16 \\
\hline Police & 0.06 & 0.04 & 0.08 & 0.05 & 0.09 & 0.06 & 0.10 & 0.06 \\
\hline Fire Protection & 0.02 & 0.02 & 0.03 & 0.03 & 0.03 & 0.03 & 0.04 & 0.03 \\
\hline Public Buildings & 0.01 & 0.03 & 0.02 & 0.08 & 0.02 & 0.02 & 0.02 & 0.02 \\
\hline \multicolumn{9}{|l|}{ Demographics } \\
\hline Median Family Income (thous) & 3.46 & 0.77 & 3.76 & 0.96 & 3.81 & 0.93 & 4.05 & 0.95 \\
\hline Employment/Population & 0.43 & 0.14 & 0.46 & 0.12 & 0.48 & 0.14 & 0.52 & 0.15 \\
\hline Pct Black & 8.46 & 14.30 & 8.45 & 14.25 & 8.51 & 14.23 & 8.68 & 14.35 \\
\hline Pct Hispanic & 3.88 & 10.33 & 4.22 & 10.76 & 4.78 & 11.21 & 5.65 & 11.66 \\
\hline Pct Poor & 12.52 & 6.54 & 12.84 & 6.83 & 12.30 & 6.56 & 11.18 & 5.93 \\
\hline Pct Urban & 35.50 & 28.81 & 35.58 & 29.03 & 36.52 & 29.11 & 38.67 & 29.69 \\
\hline Population & 71,943 & 236,393 & 75,260 & 251,489 & 81,737 & 295,105 & 85,865 & 303,312 \\
\hline
\end{tabular}

Notes:

Sources:
All revenue and expenditure variables are in thousands of per capita, real year 2000 dollars. Totals are calculated as the sum of observed components.

U.S. Bureau of the Census, Census of Governments and Area Resource File, various years. 
Table 2: Court Rulings of Unconstitutional School

Finance Systems (through 1997)

\begin{tabular}{ll}
\hline \hline \multicolumn{1}{c}{ State } & \multicolumn{1}{c}{ Year(s) of Ruling(s) } \\
\hline Alabama & 1993,1997 \\
Arizona & 1994,1997 \\
Arkansas & 1983 \\
California & 1971,1977 \\
Connecticut & 1977,1996 \\
Kansas & 1976 \\
Kentucky & 1989 \\
Massachusetts & 1993 \\
Missouri & 1996 \\
Montana & 1989 \\
New Hampshire & 1993,1997 \\
New Jersey & $1973,1976,1990,1994,1997$ \\
North Carolina & 1997 \\
Ohio & 1997 \\
Rhode Island & 1994 \\
Tennessee & 1993,1995 \\
Texas & 1989,1991 \\
Vermont & 1997 \\
Washington & 1978,1991 \\
West Virginia & 1979,1988 \\
Wisconsin & 1976 \\
Wyoming & 1980,1995 \\
& \\
\hline
\end{tabular}

Sources: Card and Payne (2002), Corcoran et al. (2003), and Hoxby (2000). Corcoran et al. cite Minorini and Sugarman (1999).

Note that there is disagreement among these three sources in several cases. We generally follow Card and Payne for rulings through 1992, using Corcoran et al. for rulings post-1992. Two exceptions are: Card and Payne list New Jersey rulings in 1989 and 1991; we follow Corcoran et al. in listing Abbott v. Burke II in 1990 (see Abbott v. Burke II, 119 N.J. 287, 575 A.2d 359 (1990)). Card and Payne list a West Virginia ruling in 1978, but we follow Corcoran et al. in listing Pauley v. Kelley (I) in 1979 (see Pauley v. Kelley, 162 W. Va. 672, 255 SE.2d 859 (1979)). 
Table 3: Effect of SFEs on Aggregate State Budgets

\begin{tabular}{|c|c|c|c|c|c|c|c|c|c|}
\hline & $\begin{array}{c}\text { Total } \\
\text { Expend }\end{array}$ & $\begin{array}{c}\text { Total IG } \\
\text { Exp }\end{array}$ & $\begin{array}{l}\text { Elem-Sec } \\
\text { Educ Exp }\end{array}$ & $\begin{array}{l}\text { IG Elem- } \\
\text { Sec Educ } \\
\text { Exp }\end{array}$ & $\begin{array}{c}\text { Welfare } \\
\text { Exp }\end{array}$ & Total Rev & $\begin{array}{l}\text { Income } \\
\text { tax rev }\end{array}$ & $\begin{array}{c}\text { Sales } \\
\text { tax rev }\end{array}$ & $\begin{array}{c}\text { Rev from } \\
\text { charges }\end{array}$ \\
\hline SFE dummy & $\begin{array}{l}0.077 \\
(.046)\end{array}$ & $\begin{array}{c}0.026 \\
(.025)\end{array}$ & $\begin{array}{l}0.022 \\
(.014)\end{array}$ & $\begin{array}{l}0.021 \\
(.013)\end{array}$ & $\begin{array}{c}0.282 \\
(.013)\end{array}$ & $\begin{array}{l}0.031 \\
(.078)\end{array}$ & $\begin{array}{r}-0.014 \\
(.020)\end{array}$ & $\begin{array}{l}0.014 \\
(.011)\end{array}$ & $\begin{array}{l}0.020 \\
(.037)\end{array}$ \\
\hline State-year obs & 784 & 784 & 784 & 784 & 784 & 784 & 784 & 784 & 784 \\
\hline State obs & 49 & 49 & 49 & 49 & 49 & 49 & 49 & 49 & 49 \\
\hline R-squared & 0.75 & 0.47 & 0.75 & 0.89 & 0.38 & 0.84 & 0.39 & 0.61 & 0.13 \\
\hline
\end{tabular}

Notes:

Data represent annual state-level observations from 1982-97.

All revenue and expenditure variables are in thousands of per capita, real year 2000 dollars. All regressions are OLS and control for state and year fixed effects, and state demographics (population, mean personal income, and percent poor). Standard errors in parentheses.

Source: U.S. Bureau of the Census, Census of Governments (state files), various years. 
Table 4: Effect of SFEs on Distribution of State IG Spending

\begin{tabular}{|c|c|c|c|c|c|c|}
\hline \multirow[b]{2}{*}{ SFE } & \multicolumn{2}{|c|}{$\begin{array}{c}\text { State Education } \\
\text { Revenue to Localities }\end{array}$} & \multicolumn{2}{|c|}{$\begin{array}{l}\text { State Non-Education } \\
\text { Revenue to Localities }\end{array}$} & \multicolumn{2}{|c|}{$\begin{array}{c}\text { Total State Revenue to } \\
\text { Localities }\end{array}$} \\
\hline & $\begin{array}{r}0.051 \\
(.005)\end{array}$ & $\begin{array}{r}0.012 \\
(.006)\end{array}$ & $\begin{array}{l}-0.012 \\
(.004)\end{array}$ & $\begin{array}{l}-0.018 \\
(.005)\end{array}$ & $\begin{array}{r}0.039 \\
(.006)\end{array}$ & $\begin{array}{l}-0.007 \\
(.008)\end{array}$ \\
\hline Relative median family income & $\begin{array}{l}-0.028 \\
(.009)\end{array}$ & $\begin{array}{l}-0.018 \\
(.009)\end{array}$ & $\begin{array}{l}-0.019 \\
(.007)\end{array}$ & $\begin{array}{c}-0.018 \\
(.007)\end{array}$ & $\begin{array}{l}-0.044 \\
(.011)\end{array}$ & $\begin{array}{l}-0.034 \\
(.011)\end{array}$ \\
\hline SFE*Relative median family income & & $\begin{array}{l}-0.051 \\
(.005)\end{array}$ & & $\begin{array}{l}-0.009 \\
(.004)\end{array}$ & & $\begin{array}{l}-0.059 \\
(.006)\end{array}$ \\
\hline $\begin{array}{l}\text { Observations } \\
\text { R-squared }\end{array}$ & $\begin{array}{r}12124 \\
0.85\end{array}$ & $\begin{array}{r}12124 \\
0.85\end{array}$ & $\begin{array}{r}12123 \\
0.86\end{array}$ & $\begin{array}{r}12123 \\
0.86\end{array}$ & $\begin{array}{r}12150 \\
0.87\end{array}$ & $\begin{array}{r}12150 \\
0.87\end{array}$ \\
\hline
\end{tabular}

Notes: $\quad$ Data represent annual county-area observations from 1982, 87, 92, and 97. SEs in parentheses.

All revenue and expenditure variables are in thousands of per capita, real year 2000 dollars.

All regressions control for county-area and year fixed effects, and county-level demographics (population, employment/population ratio, median family income, percent black, percent Hispanic, percent poor, and percent urban).

Sources: $\quad$ U.S. Bureau of the Census, Census of Governments and Area Resource File, various years. 
Table 5: OLS Estimates of County Responses

\begin{tabular}{|c|c|c|c|c|c|c|c|c|c|}
\hline \multirow{2}{*}{$\begin{array}{l}\text { State IG Education } \\
\text { Revenues to County }\end{array}$} & \multicolumn{9}{|c|}{ Revenues } \\
\hline & $\begin{array}{r}\text { Total Revenue } \\
0.637 \\
(.028)\end{array}$ & $\begin{array}{l}\text { IG Rev } \\
\text { from Fed } \\
0.006 \\
(.005)\end{array}$ & $\begin{array}{r}\text { IG Rev } \\
\text { from State } \\
\\
1.044 \\
(.008)\end{array}$ & $\begin{array}{c}\text { Non-Ed } \\
\text { IG Rev } \\
\text { from } \\
\text { State } \\
\\
0.044 \\
(.008)\end{array}$ & \multicolumn{2}{|c|}{$\begin{array}{l}\text { Highway Pub Welf } \\
\text { IG Rev IG Rev } \\
\text { from State from State }\end{array}$} & $\begin{array}{r}\begin{array}{c}\text { Hlth/Hosp } \\
\text { IG Rev } \\
\text { from State }\end{array} \\
0.000 \\
(.002)\end{array}$ & \multicolumn{2}{|c|}{$\begin{array}{l}\text { Revenue from } \\
\text { Own Sources }\end{array}$} \\
\hline \multirow[t]{2}{*}{ Observations } & 12135 & 11593 & 12133 & 12133 & 12009 & 11862 & 11807 & & 11753 \\
\hline & \multicolumn{9}{|c|}{$\begin{array}{l}\text { Expenditures } \\
\end{array}$} \\
\hline $\begin{array}{l}\text { State IG Education } \\
\text { Revenues to County }\end{array}$ & $\begin{array}{l}0.533 \\
(.023)\end{array}$ & $\begin{array}{l}0.532 \\
(.013)\end{array}$ & $\begin{array}{l}0.018 \\
(.004)\end{array}$ & $\begin{array}{r}-0.01 \\
(.014)\end{array}$ & $\begin{array}{l}0.016 \\
(.003)\end{array}$ & $\begin{array}{l}0.005 \\
(.007)\end{array}$ & $\begin{array}{r}-0.003 \\
(.002)\end{array}$ & $\begin{array}{r}-0.007 \\
(.001)\end{array}$ & $\begin{array}{r}-0.002 \\
(.004)\end{array}$ \\
\hline Observations & 12135 & 12135 & 11734 & 11977 & 11882 & 12110 & 12124 & 11992 & 11938 \\
\hline
\end{tabular}

Notes:

Data represent annual county-area observations from 1982, 87, 92, and 97. SEs in parentheses.

All revenue and expenditure variables are in thousands of per capita, real year 2000 dollars.

All regressions control for county-area and year fixed effects, and county-level demographics (population, employment/population ratio, median family income, percent black, percent Hispanic, percent poor, and percent urban).

Sources: $\quad$ U.S. Bureau of the Census, Census of Governments and Area Resource File, various years. 
Table 6: IV Estimates of County Responses

Instrument is Presence of Court-Ordered School Finance Equalization

\begin{tabular}{|c|c|c|c|c|c|c|c|c|c|}
\hline \multirow[b]{3}{*}{$\begin{array}{l}\text { State IG Education } \\
\text { Revenues to County }\end{array}$} & \multicolumn{9}{|c|}{ Revenues } \\
\hline & Total Revenue & $\begin{array}{l}\text { IG Rev } \\
\text { from Fed }\end{array}$ & $\begin{array}{c}\text { IG Rev } \\
\text { from State }\end{array}$ & $\begin{array}{l}\text { Non-Ed IG } \\
\text { Rev from } \\
\text { State }\end{array}$ & $\begin{array}{l}\text { Highway IG } \\
\text { Rev from } \\
\text { State }\end{array}$ & $\begin{array}{l}\text { Pub Welf } \\
\text { IG Rev } \\
\text { from State }\end{array}$ & $\begin{array}{c}\text { Hlth/Hosp } \\
\text { IG Rev } \\
\text { from State }\end{array}$ & $\begin{array}{l}\text { Reven } \\
\text { Own } s\end{array}$ & $\begin{array}{l}\text { lue from } \\
\text { Sources }\end{array}$ \\
\hline & $\begin{array}{l}0.295 \\
(.250)\end{array}$ & $\begin{array}{r}-0.035 \\
(.045)\end{array}$ & $\begin{array}{l}0.779 \\
(.080)\end{array}$ & $\begin{array}{r}-0.221 \\
(.080)\end{array}$ & $\begin{array}{r}-0.080 \\
(.041)\end{array}$ & $\begin{array}{r}-0.071 \\
(.022)\end{array}$ & $\begin{array}{r}-0.043 \\
(.018)\end{array}$ & & $\begin{array}{l}-0.294 \\
(.313)\end{array}$ \\
\hline \multirow[t]{3}{*}{ Observations } & 12135 & 11593 & 12133 & 12133 & 12009 & 11862 & 11807 & & 11753 \\
\hline & \multicolumn{9}{|c|}{ Expenditures } \\
\hline & $\begin{array}{l}\text { Tot Direct } \\
\text { Expenditure }\end{array}$ & $\begin{array}{l}\text { Exp on } \\
\text { Educ }\end{array}$ & $\begin{array}{l}\text { Exp on Pub } \\
\text { Welf }\end{array}$ & $\begin{array}{l}\text { Exp on } \\
\text { Hosps }\end{array}$ & $\begin{array}{l}\text { Exp on } \\
\text { Health }\end{array}$ & $\begin{array}{l}\text { Exp on } \\
\text { Highways }\end{array}$ & $\begin{array}{l}\text { Exp on } \\
\text { Police }\end{array}$ & $\begin{array}{l}\text { Exp on } \\
\text { Fire Prot }\end{array}$ & $\begin{array}{c}\text { Exp on Pub } \\
\text { Bldgs }\end{array}$ \\
\hline $\begin{array}{l}\text { State IG Education } \\
\text { Revenues to County }\end{array}$ & $\begin{array}{r}-0.288 \\
(.220)\end{array}$ & $\begin{array}{l}0.860 \\
(.119)\end{array}$ & $\begin{array}{r}-0.069 \\
(.038)\end{array}$ & $\begin{array}{r}-0.486 \\
(.136)\end{array}$ & $\begin{array}{r}-0.097 \\
(.033)\end{array}$ & $\begin{array}{r}-0.288 \\
(.070)\end{array}$ & $\begin{array}{r}-0.042 \\
(.020)\end{array}$ & $\begin{array}{r}-0.045 \\
(.012)\end{array}$ & $\begin{array}{r}-0.055 \\
(.037)\end{array}$ \\
\hline Observations & 12135 & 12135 & 11734 & 11977 & 11882 & 12110 & 12124 & 11992 & 11938 \\
\hline
\end{tabular}

Notes:

Data represent annual county-area observations from 1982, 87, 92, and 97. SEs in parentheses.

All revenue and expenditure variables are in thousands of per capita, real year 2000 dollars.

All regressions control for county-area and year fixed effects, and county-level demographics (population, employment/population ratio, median family income, percent black, percent Hispanic, percent poor, and percent urban).

Sources: $\quad$ U.S. Bureau of the Census, Census of Governments and Area Resource File, various years. 
Table 7: Alternative Specifications

\begin{tabular}{|c|c|c|c|c|c|c|c|c|c|c|c|c|c|c|c|c|}
\hline & \multicolumn{8}{|c|}{ IV Fixed Effects } & \multicolumn{4}{|c|}{ IV Random Effects } & \multicolumn{4}{|c|}{ Propensity Score Matching } \\
\hline & \multicolumn{2}{|c|}{$\begin{array}{l}\text { Total IG Rev from } \\
\text { State }\end{array}$} & \multicolumn{2}{|c|}{$\begin{array}{l}\text { Revenue from } \\
\text { Own Sources }\end{array}$} & \multicolumn{2}{|c|}{$\begin{array}{c}\text { Total } \\
\text { Expenditures }\end{array}$} & \multicolumn{2}{|c|}{$\begin{array}{c}\text { Education } \\
\text { Expenditures }\end{array}$} & $\begin{array}{l}\text { Total IG } \\
\text { Rev from } \\
\text { State }\end{array}$ & $\begin{array}{l}\text { Rev from } \\
\text { Own } \\
\text { Sources }\end{array}$ & $\begin{array}{c}\text { Total } \\
\text { Expend }\end{array}$ & $\begin{array}{l}\text { Education } \\
\text { Expend }\end{array}$ & $\begin{array}{l}\text { Total IG } \\
\text { Rev from } \\
\text { State }\end{array}$ & $\begin{array}{l}\text { Rev from } \\
\text { Own } \\
\text { Sources }\end{array}$ & $\begin{array}{c}\text { Total } \\
\text { Expend }\end{array}$ & $\begin{array}{l}\text { Education } \\
\text { Expend }\end{array}$ \\
\hline $\begin{array}{l}\text { IG Education Revenues } \\
\text { from State to County }\end{array}$ & $\begin{array}{l}0.779 \\
(.080)\end{array}$ & $\begin{array}{l}0.807 \\
0.076\end{array}$ & $\begin{array}{r}-0.294 \\
(.313)\end{array}$ & $\begin{array}{r}-0.305 \\
(.300)\end{array}$ & $\begin{array}{r}-0.288 \\
(.220)\end{array}$ & $\begin{array}{r}-0.25 \\
(.209)\end{array}$ & $\begin{array}{l}0.860 \\
(.119)\end{array}$ & $\begin{array}{l}0.839 \\
(.113)\end{array}$ & $\begin{array}{l}0.813 \\
(.069)\end{array}$ & $\begin{array}{l}0.055 \\
(.262)\end{array}$ & $\begin{array}{l}0.175 \\
(.183)\end{array}$ & $\begin{array}{l}0.899 \\
(.101)\end{array}$ & $\begin{array}{l}1.035 \\
(.090)\end{array}$ & $\begin{array}{r}-0.399 \\
(.036)\end{array}$ & $\begin{array}{l}0.518 \\
(.023)\end{array}$ & $\begin{array}{l}0.518 \\
(.013)\end{array}$ \\
\hline Time Dummies & Yes & Yes & Yes & Yes & Yes & Yes & Yes & Yes & Yes & Yes & Yes & Yes & Yes & Yes & Yes & Yes \\
\hline $\begin{array}{l}\text { Time Dummies } \\
\text { Interacted with "Poor } \\
\text { County in Initial Period" } \\
\text { Dummy }\end{array}$ & No & Yes & No & Yes & No & Yes & No & Yes & No & No & No & No & No & No & No & No \\
\hline
\end{tabular}

Notes:

Data represent annual county-area observations from 1982, 87, 92, and 97. SEs in parentheses.

All revenue and expenditure variables are in thousands of per capita, real year 2000 dollars.

IV regressions in first two panels control for county-area and year fixed effects, and county-level demographics (population, employment/population ratio, median family income, percent black, percent Hispanic, percent poor, and percent urban). IV is presence of court-ordered school finance equalization.

Propensity score matching in third panel is performed using covariates listed above, and the propensity score and propensity score squared are included in second stage regressions.

Sources:

U.S. Bureau of the Census, Census of Governments and Area Resource File, various years. 
Table 8: Heterogeneity of Responses Based on Income

Instruments are Presence of Court-Ordered School Finance Equalization and Interaction with Relative Income

\begin{tabular}{|c|c|c|c|c|c|c|c|c|c|c|c|c|c|c|c|c|c|c|}
\hline \multirow[b]{3}{*}{$\begin{array}{l}\text { State IG Education } \\
\text { Revenues to County }\end{array}$} & \multicolumn{18}{|c|}{$\begin{array}{l}\text { Revenues } \\
\text { Ren }\end{array}$} \\
\hline & \multicolumn{2}{|c|}{ Total Revenue } & \multicolumn{2}{|c|}{ IG Rev from Fed } & \multicolumn{2}{|c|}{ IG Rev from State } & \multicolumn{2}{|c|}{$\begin{array}{c}\text { Non-Ed IG Rev from } \\
\text { State }\end{array}$} & \multicolumn{2}{|c|}{$\begin{array}{l}\text { Highway IG Rev } \\
\text { from State }\end{array}$} & \multicolumn{2}{|c|}{$\begin{array}{l}\text { Pub Welf IG Rev } \\
\text { from State }\end{array}$} & \multicolumn{2}{|c|}{$\begin{array}{l}\text { Hlth/Hosp IG Rev } \\
\text { from State }\end{array}$} & \multicolumn{4}{|c|}{$\begin{array}{l}\text { Revenue from } \\
\text { Own Sources }\end{array}$} \\
\hline & $\begin{array}{l}0.221 \\
(.331)\end{array}$ & $\begin{array}{r}0.507 \\
(.321)\end{array}$ & $\begin{array}{r}-0.059 \\
(.059)\end{array}$ & $\begin{array}{r}-0.072 \\
(.058)\end{array}$ & $\begin{array}{l}0.662 \\
(.107)\end{array}$ & $\begin{array}{r}0.73 \\
(.103)\end{array}$ & $\begin{array}{l}-0.338 \\
(.107)\end{array}$ & $\begin{array}{r}-0.270 \\
(.103)\end{array}$ & $\begin{array}{l}-0.119 \\
(.054)\end{array}$ & $\begin{array}{r}-0.107 \\
(.052)\end{array}$ & $\begin{array}{l}-0.098 \\
(.030)\end{array}$ & $\begin{array}{l}-0.081 \\
(.029)\end{array}$ & $\begin{array}{r}-0.055 \\
(.023)\end{array}$ & $\begin{array}{r}-0.042 \\
(.023)\end{array}$ & & $\begin{array}{l}-0.163 \\
(.416)\end{array}$ & $\begin{array}{l}0.328 \\
(.408)\end{array}$ & \\
\hline $\begin{array}{l}\text { State IG Ed Rev * } \\
\text { Relative Income }\end{array}$ & $\begin{array}{l}-0.079 \\
(.109)\end{array}$ & & $\begin{array}{r}-0.026 \\
(.020)\end{array}$ & & $\begin{array}{r}-0.123 \\
(.035)\end{array}$ & & $\begin{array}{r}-0.123 \\
(.035)\end{array}$ & & $\begin{array}{r}-0.042 \\
(.018)\end{array}$ & & $\begin{array}{r}-0.028 \\
(.010)\end{array}$ & & $\begin{array}{r}-0.013 \\
(.008)\end{array}$ & & & $\begin{array}{l}0.139 \\
(.138)\end{array}$ & & \\
\hline $\begin{array}{l}\text { State IG Ed Rev* } \\
\text { Relative Inc for Low } \\
\text { Income Counties }\end{array}$ & & $\begin{array}{r}0.093 \\
(.106)\end{array}$ & & $\begin{array}{r}-0.033 \\
(.019)\end{array}$ & & $\begin{array}{r}-0.082 \\
(.034)\end{array}$ & & $\begin{array}{r}-0.082 \\
(.034)\end{array}$ & & $\begin{array}{r}-0.035 \\
(.017)\end{array}$ & & $\begin{array}{r}-0.018 \\
(.009)\end{array}$ & & $\begin{array}{r}-0.006 \\
(.008)\end{array}$ & & & $\begin{array}{l}0.434 \\
(.136)\end{array}$ & \\
\hline $\begin{array}{l}\text { State IG Ed Rev* } \\
\text { Relative Inc for High } \\
\text { Income Counties }\end{array}$ & & $\begin{array}{r}-0.867 \\
(.417)\end{array}$ & & $\begin{array}{l}0.007 \\
(.072)\end{array}$ & & $\begin{array}{r}-0.310 \\
(.134)\end{array}$ & & $\begin{array}{l}-0.310 \\
(.134)\end{array}$ & & $\begin{array}{r}-0.075 \\
(.066)\end{array}$ & & $\begin{array}{l}-0.074 \\
(.037)\end{array}$ & & $\begin{array}{r}-0.046 \\
(.029)\end{array}$ & & & $\begin{array}{r}-1.165 \\
(.520)\end{array}$ & \\
\hline \multirow{3}{*}{$\begin{array}{l}\text { Prob. Low }=\text { High } \\
\text { Observations }\end{array}$} & & 0.029 & & 0.596 & & 0.106 & & 0.106 & & 0.564 & & 0.143 & & 0.194 & & & 0.004 & \\
\hline & \multicolumn{18}{|c|}{ Expenditures } \\
\hline & \multicolumn{2}{|c|}{$\begin{array}{l}\text { Total Direct } \\
\text { Expenditure }\end{array}$} & \multicolumn{2}{|c|}{ Exp on Educ } & \multicolumn{2}{|c|}{ Exp on Pub Welf } & \multicolumn{2}{|c|}{ Exp on Hosps } & \multicolumn{2}{|c|}{ Exp on Health } & \multicolumn{2}{|c|}{ Exp on Highways } & \multicolumn{2}{|c|}{ Exp on Police } & \multicolumn{2}{|c|}{ Exp on Fire Prot } & \multicolumn{2}{|c|}{ Exp on Pub Bldgs } \\
\hline $\begin{array}{l}\text { State IG Education } \\
\text { Revenues to County }\end{array}$ & $\begin{array}{l}-0.513 \\
(.292)\end{array}$ & $\begin{array}{r}-0.276 \\
(.281)\end{array}$ & $\begin{array}{l}0.932 \\
(.157)\end{array}$ & $\begin{array}{l}0.965 \\
(.152)\end{array}$ & $\begin{array}{l}-0.101 \\
(.049)\end{array}$ & $\begin{array}{l}-0.069 \\
(.049)\end{array}$ & $\begin{array}{l}-0.571 \\
(.179)\end{array}$ & $\begin{array}{l}-0.454 \\
(.174)\end{array}$ & $\begin{array}{l}-0.121 \\
(.043)\end{array}$ & $\begin{array}{l}-0.102 \\
(.042)\end{array}$ & $\begin{array}{l}-0.39 \\
(.093)\end{array}$ & $\begin{array}{l}-0.386 \\
(.090)\end{array}$ & $\begin{array}{l}-0.045 \\
(.026)\end{array}$ & $\begin{array}{r}-0.039 \\
(.025)\end{array}$ & $\begin{array}{l}-0.054 \\
(.016)\end{array}$ & $\begin{array}{l}-0.055 \\
(.016)\end{array}$ & $\begin{array}{r}-0.074 \\
(.049)\end{array}$ & $\begin{array}{r}-0.075 \\
(.047)\end{array}$ \\
\hline $\begin{array}{l}\text { State IG Ed Rev * } \\
\text { Relative Income }\end{array}$ & $\begin{array}{l}-0.24 \\
(.096)\end{array}$ & & $\begin{array}{l}0.077 \\
(.052)\end{array}$ & & $\begin{array}{r}-0.035 \\
(.016)\end{array}$ & & $\begin{array}{r}-0.092 \\
(.059)\end{array}$ & & $\begin{array}{r}-0.026 \\
(.014)\end{array}$ & & $\begin{array}{l}-0.108 \\
(.031)\end{array}$ & & $\begin{array}{r}-0.003 \\
(.009)\end{array}$ & & $\begin{array}{r}-0.010 \\
(.005)\end{array}$ & & $\begin{array}{r}-0.020 \\
(.016)\end{array}$ & \\
\hline $\begin{array}{l}\text { State IG Ed Rev * } \\
\text { Relative Inc for Low } \\
\text { Income Counties }\end{array}$ & & $\begin{array}{r}-0.097 \\
(.093)\end{array}$ & & $\begin{array}{c}0.097 \\
(.050)\end{array}$ & & $\begin{array}{r}-0.017 \\
(.016)\end{array}$ & & $\begin{array}{l}-0.021 \\
(.058)\end{array}$ & & $\begin{array}{r}-0.015 \\
(.014)\end{array}$ & & $\begin{array}{r}-0.106 \\
(.030)\end{array}$ & & $\begin{array}{r}0.000 \\
(.008)\end{array}$ & & $\begin{array}{r}-0.010 \\
(.005)\end{array}$ & & $\begin{array}{r}-0.021 \\
(.015)\end{array}$ \\
\hline $\begin{array}{l}\text { State IG Ed Rev* } \\
\text { Relative Inc for High } \\
\text { Income Counties }\end{array}$ & & $\begin{array}{r}-0.892 \\
(.365)\end{array}$ & & $\begin{array}{l}-0.012 \\
(.198)\end{array}$ & & $\begin{array}{r}-0.11 \\
(.054)\end{array}$ & & $\begin{array}{l}-0.414 \\
(.226)\end{array}$ & & $\begin{array}{l}-0.076 \\
(.051)\end{array}$ & & $\begin{array}{l}-0.119 \\
(.116)\end{array}$ & & $\begin{array}{r}-0.019 \\
(.033)\end{array}$ & & $\begin{array}{r}-0.008 \\
(.020)\end{array}$ & & $\begin{array}{r}-0.018 \\
(.060)\end{array}$ \\
\hline $\begin{array}{l}\text { Prob. Low }=\text { High } \\
\text { Observations }\end{array}$ & & 0.039 & & 0.604 & & 0.107 & & 0.101 & & 0.263 & & 0.915 & & 0.578 & & 0.918 & & 0.958 \\
\hline
\end{tabular}

Notes:

Data represent annual county-area observations from 1982, 87, 92, and 97. SEs in parentheses.

All revenue and expenditure variables are in thousands of per capita, real year 2000 dollars.

All regressions control for county-area and year fixed effects, and county-level demographics (population, employment/population ratio, median family income, percent black, percent Hispanic, percent poor, and percent urban).

Sources:

U.S. Bureau of the Census, Census of Governments and Area Resource File, various years. 
Table 9: Other Sources of Heterogeneity of Responses

\begin{tabular}{|c|c|c|c|c|c|c|c|c|c|c|c|c|}
\hline \multirow[t]{2}{*}{ Interaction: } & \multicolumn{4}{|c|}{ Tax and Expenditure Limits } & \multicolumn{4}{|c|}{ High Home Ownership } & \multicolumn{4}{|c|}{ More Local Control } \\
\hline & $\begin{array}{l}\text { Total IG Rev } \\
\text { from State }\end{array}$ & $\begin{array}{l}\text { Rev from Own } \\
\text { Sources }\end{array}$ & $\begin{array}{l}\text { Total } \\
\text { Expend }\end{array}$ & $\begin{array}{l}\text { Education } \\
\text { Expend }\end{array}$ & $\begin{array}{l}\text { Total IG Rev } \\
\text { from State }\end{array}$ & $\begin{array}{l}\text { Rev from Own } \\
\text { Sources }\end{array}$ & $\begin{array}{l}\text { Total } \\
\text { Expend }\end{array}$ & $\begin{array}{l}\text { Education } \\
\text { Expend }\end{array}$ & $\begin{array}{l}\text { Total IG Rev } \\
\text { from State }\end{array}$ & $\begin{array}{l}\text { Rev from Own } \\
\text { Sources }\end{array}$ & $\begin{array}{l}\text { Total } \\
\text { Expend }\end{array}$ & $\begin{array}{l}\text { Education } \\
\text { Expend }\end{array}$ \\
\hline $\begin{array}{l}\text { IG Educ Rev from } \\
\text { State to County }\end{array}$ & $\begin{array}{l}0.476 \\
(.139)\end{array}$ & $\begin{array}{r}-0.094 \\
(.492)\end{array}$ & $\begin{array}{l}-0.411 \\
(.348)\end{array}$ & $\begin{array}{l}1.160 \\
(.195)\end{array}$ & $\begin{array}{l}0.715 \\
(.110)\end{array}$ & $\begin{array}{r}-0.295 \\
(.435)\end{array}$ & $\begin{array}{r}-0.485 \\
(.302)\end{array}$ & $\begin{array}{r}0.890 \\
(.163)\end{array}$ & $\begin{array}{l}0.694 \\
(.092)\end{array}$ & $\begin{array}{r}-0.296 \\
(.361)\end{array}$ & $\begin{array}{r}-0.400 \\
(.252)\end{array}$ & $\begin{array}{l}0.930 \\
(.136)\end{array}$ \\
\hline Interaction Term & $\begin{array}{l}0.156 \\
(.049)\end{array}$ & $\begin{array}{r}-0.103 \\
(.173)\end{array}$ & $\begin{array}{r}0.063 \\
(.121)\end{array}$ & $\begin{array}{r}-0.155 \\
(.068)\end{array}$ & $\begin{array}{l}0.073 \\
(.060)\end{array}$ & $\begin{array}{l}0.001 \\
(.238)\end{array}$ & $\begin{array}{l}0.227 \\
(.164)\end{array}$ & $\begin{array}{r}-0.034 \\
(.088)\end{array}$ & $\begin{array}{l}0.114 \\
(.038)\end{array}$ & $\begin{array}{l}0.002 \\
(.149)\end{array}$ & $\begin{array}{l}0.151 \\
(.103)\end{array}$ & $\begin{array}{r}-0.094 \\
(.055)\end{array}$ \\
\hline \multirow[t]{2}{*}{ Interaction: } & \multicolumn{4}{|c|}{ Large Poor Population } & \multicolumn{4}{|c|}{ Dependent School Districts } & \multicolumn{4}{|c|}{ Large Black Population } \\
\hline & $\begin{array}{l}\text { Total IG Rev } \\
\text { from State }\end{array}$ & $\begin{array}{l}\text { Rev from Own } \\
\text { Sources }\end{array}$ & $\begin{array}{l}\text { Total } \\
\text { Expend }\end{array}$ & $\begin{array}{l}\text { Education } \\
\text { Expend }\end{array}$ & $\begin{array}{l}\text { Total IG Rev } \\
\text { from State }\end{array}$ & $\begin{array}{l}\text { Rev from Own } \\
\text { Sources }\end{array}$ & $\begin{array}{l}\text { Total } \\
\text { Expend }\end{array}$ & $\begin{array}{l}\text { Education } \\
\text { Expend }\end{array}$ & $\begin{array}{l}\text { Total IG Rev } \\
\text { from State }\end{array}$ & $\begin{array}{l}\text { Rev from Own } \\
\text { Sources }\end{array}$ & $\begin{array}{l}\text { Total } \\
\text { Expend }\end{array}$ & $\begin{array}{l}\text { Education } \\
\text { Expend }\end{array}$ \\
\hline $\begin{array}{l}\text { IG Educ Rev from } \\
\text { State to County }\end{array}$ & $\begin{array}{l}0.664 \\
(.109)\end{array}$ & $\begin{array}{r}-0.033 \\
(.423)\end{array}$ & $\begin{array}{l}-0.527 \\
(.298)\end{array}$ & $\begin{array}{r}0.932 \\
(.160)\end{array}$ & $\begin{array}{l}0.776 \\
(.080)\end{array}$ & $\begin{array}{r}-0.265 \\
(.314)\end{array}$ & $\begin{array}{r}-0.321 \\
(.221)\end{array}$ & $\begin{array}{l}0.832 \\
(.118)\end{array}$ & $\begin{array}{l}0.788 \\
(.078)\end{array}$ & $\begin{array}{r}-0.281 \\
(.307)\end{array}$ & $\begin{array}{r}-0.274 \\
(.215)\end{array}$ & $\begin{array}{l}0.856 \\
(.116)\end{array}$ \\
\hline Interaction Term & $\begin{array}{l}0.168 \\
(.056)\end{array}$ & $\begin{array}{l}-0.385 \\
(.220)\end{array}$ & $\begin{array}{r}0.350 \\
(.154)\end{array}$ & $\begin{array}{r}-0.106 \\
(.083)\end{array}$ & $\begin{array}{r}0.016 \\
(.055)\end{array}$ & $\begin{array}{r}-0.145 \\
(.218)\end{array}$ & $\begin{array}{r}0.170 \\
(.151)\end{array}$ & $\begin{array}{c}0.142 \\
(.081)\end{array}$ & $\begin{array}{r}-0.053 \\
(.047)\end{array}$ & $\begin{array}{r}-0.085 \\
(.187)\end{array}$ & $\begin{array}{r}-0.079 \\
(.129)\end{array}$ & $\begin{array}{r}0.025 \\
(.069)\end{array}$ \\
\hline
\end{tabular}

Notes: $\quad$ Data represent annual county-area observations from 1982, 87, 92, and 97. SEs in parentheses.

All revenue and expenditure variables are in thousands of per capita, real year 2000 dollars.

All regressions control for county-area and year fixed effects, and county-level demographics (population, employment/population ratio, median family income, percent black, percent Hispanic, percent poor, and percent urban).

Interaction terms are all measured in the initial period and constant over time. Home ownership (percent of population owning home) and local control (local revenues from own sources/state revenues from own sources) are dummy variables for values higher than the median in the initial period.

Sources: $\quad$ U.S. Bureau of the Census, Census of Governments and Area Resource File, various years. 